lus, or its development, or its culture, before it invades the race by the individual, that is, should create in the organism such conditions, should produce such constitutions, as would not allow of the existence of these microscopical pestilences. That would be asepsis instead of antisepsis. Here is what asepsis has to do. It stands at the fountain head, its mission is to keep the spring of life free from impurity. Let a commission, or whatever body of scientific information and action, go to Russia, to the original habitat of the typhus germ, oppose the development of its colonies before they begin their trip around the world. The first thing to do will probably be to improve the condition of the Russian Jew. Prevent the Hindoos from poisoning themselves with their holy water, with which they drink the blessing of cholera. Enact laws to isolate the syphilitic and the tuberculous. Prohibit the marriage of such. Let the congenitally incurable die before puberty: it is better that the offending limb should be lost than that tubercułosis, syphilis, leprosy, etc., should spread through the whole body. Let the healthy, the temperate, the moral, alone have the inheritance. A correct life is the most perfect asepsis, and insures an immunity with which the burnt infant's immunity, known as such, cannot compare.

\section{THE "GOPHER FROG."}

BY FREDERICK CLEVELAND TEST, U. S. NATIONAL MUSEUM, WASHINGTON, D. C.

Through the kindness of Mr. H. G. Hubbard, of Crescent City, Florida, I am enabled to make a note on the habits of the "gopher frog," Rana areolata osopus, Cope. This form seems to be so rare in collections that so far the only specimen reported as having been identified with this sub-species is the type in the National Museum, from Micanopy, Nlorida, and described by Professor Cope in the Proceedings of the American Philosophical Society for 1885. I have been unable to find any published mention of its habits, which are peculiar.

It appears to be almost entirely subterranean in its habits, living in the holes and burrows of the "gopher" turtle, Gopherus polyphemus, in conjunction with it, and apparently on the best of terms. Roughly described, it is grayish green, with thirty-five or forty ragged black spots arranged in four or five irregular longitudinal rows on the back, and grading off into smaller spots on the flanks, while the legs are barred with about fifteen half-rings of black, from the thighs to the toes. Beneath it is white, with the throat marbled with very dark brown. The body is rather flat, with wide head and sharp-pointed snout, and the two dorso-lateral ridges, together with indicated folds between them, are greenish brown. The size is about that of a small "leopard frog," Rana pipilus, or the "swamp frog," Rana palustris, to which last it is closely related, although individuals are said to have been seen weighing two or three pounds. But those must have been huge toads, noticed by persons unable to distinguish between them and the frogs, or too unobserving to make the distinction. Its food has not been ascertained, from dissection of the stomachs of freshly captured specimens, but as these frogs are rarely seen away from the burrows, it is probable that they feed on the insects living in the burrows, for the holes possess a flourishing insect fauna, to a grest extent peculiar to them.

On cloudy and rainy days the frogs sit at the mouths of the burrows-as many as three have been found in a single burrow-but on the approach of a human being dive down out of sight, and as the holes are from 12 to 20 feet in length, and 7 or 8 in vertical depth at the end, digging the frogs out is no easy matter, especially as the sandy soil has a tendency to cave in on the excavator. But the frogs may be successfully angled for with a fishing line and small hook baited with a grasshopper.

In the fact that the burrows usually or always go down to water, may be found an explanation of the frogs inhabiting them, and the facility of procuring insect food therein may be an additional inducement, as well as their being safe hiding places. Nothing seems to be known of the habits of the other varieties of the species, of which also but few specimens are known, Rana areolata areolata, from Texas and Georgia, Rana areolata capito, from Georgia, and Rana areolata circulosa, the "Hoosier frog," found in Indiana and Illinois. It is to be hoped that further observations will be made upon this interesting species, and additional specimens collected.

\section{ALTTTUDE AS THE CAUSE OF THE GLACIAL PERIOD.}

BY WARREN UPHAM, SOMERVILLE, MASS.

Among the numerous difficult questions which are now being investigated and discussed by glacialists, none seems more important or worthy of attention than the cause, or the causes and conditions, which produced the Glacial period, with its very exceptional accumulation of ice-sheets upon large continental areas in the north and south temperate zones. Climatic conditions like those to-day prevailing in Greenland and on the Antarctic continent, both now covered by ice-sheets whose central portions are several thousands of feet thick, then prevailed in North America as far south as to Long Island, New York, Cincinnati, St. Louis, Bismarck and Seattle, reaching to a more southern latitude in the moist eastern half of the United States than in its mostly arid western half. Likewise Scandinavia, Great Britain south to London, Germany south to Berlin, and the northwestern half of Russia, were enveloped by ice. The glaciers of the Alps, too, of other European and Asiatic mountain ranges, of the Rocky Mountains, and of the mountains of New Zealand, were far more extensive than now; and in South America a broad ice-sheet covered Patagonia.

Three chief theories have been proposed to account for the great climatic changes made known to us by the extent of these areas of glacial drift. During the past twenty years all glacialists have been greatly interested in the astronomic theory of Dr. James Croll, so ably advocated by him in his volume, "Climate and Time," and by Prof. James Geikie in "The Great Ice Age," attributing the ice accumulation to climatic conditions attendant upon an epoch of maximum eccentricity of the earth's orbit. American glacialists, like those of Great Britain and continental Europe, were several years ago very generally inclined to think that this was a true and sufficient explanation. At the present time, however, a majority of the advanced students of this subject, at least in America, doubt that this theory is applicable to the observed facts of glaciation. For, in accordance with Dr. Croll's view, glacial periods should be recognizable with geologic frequency through the earlier Tertiary and Mesozoic eras, where, on the contrary, evidence of glacial conditions is wholly absent or exceedingly scanty, being wherever it is known probably referable to Alpine rather than continental glaciers. Besides, it seems within the past ten years to be fully ascertained that the time since the disappearance of the ice-sheets of North America and Europe has been only 6,000 to 10,000 years, whereas if they had depended on the astronomic causes mentioned their departure must have occurred some 80,000 years ago.

A second theory, accounting for the Glacial period by changes in the position of the earth's poles, and consequently in the latitude of the countries glaciated, which 
was first proposed by Sir John Evans in 1866, has therefore lately attracted the favorable consideration of some American glacialists, and in Europe has been championed by Nansen in his very interesting work, "The First Crossing of Greenland." This theory supposes that within so late a part of the earth's history as the Ice age, the north pole may have moved to the region of southern Greenland and returned, giving in the period of its digression glacial conditions for all the lands adjoining the North Atlantic Ocean, and the same for the antipodal, then south polar, portion of the globe. A small observed variation of latitude, discovered several years ago by German and Russian astronomers, seemed to give a foundation for this view, but within the past two years the brilliant investigations of Dr. S. C. Chandler, showing that these variations are of very small amount and in two short periods, one of fourteen and another of twelve months, while no appreciable secular change of latitude can be recognized, leave to us no basis for this theory of the cause of accumulation and disappearance of ice-sheets.

The third theory, which the writer believes to be applicable, sufficient and acceptable for all the observed facts of the Glacial period, attributing the ice-sheets to high altitude of the drift-bearing countries, has also been long under consideration, having been first suggested in 1855 by Dana, but failed until recently to receive adequate appreciation on account of the supposed geologic improbability of sufficiently high uplifts of so extensive portions of the earth's surface. During the past few years, however, this neglected theory has received full attestation by independent evidence, apart from the facts of glaciation, that these countries, and also other parts of the terrestrial coast, have been, in the same late geologic era which includes the Ice age, raised thousands of feet above their present height, to altitudes doubtless having so cool climate as to bring snowfall during nearly the entire year, the most favorable condition for the formation of ice-sheets. This evidence consists chiefly in the very great depth found by soundings in fjords and the submarine continuations of river valleys, where streams flowed formerly and eroded their valleys, showing these lands to have then stood far higher than now.

The Hudson River channel is traced somewhat more than a hundred miles out to sea, to a maximum depth of 2,844 feet. Similar depths are known by the United States Coast Survey and British Admiralty soundings, as Prof. J. W. Spencer has pointed out, for the former continuation of the Mississippi and St. Lawrence rivers and in the entrance of the Gulf of Maine, between Cape Cod and Nova Scotia. All about our northern and Arctic shores, from Maine around to Puget Sound, abundant fjords prove the land to have been formerly much elevated. On the coast of California, submarine valleys discovered by Professor George Davidson, of the U. S. Coast Survey, reach to depths of 2,000 to 3,120 feet; and Professor LeConte has shown that they are of late Tertiary and Quaternary age, probably contemporaneous with the submerged valleys of our Atlantic coast, and closely associated with the Glacial period. In the fluvial deposits of the Mississippi River, laid down while the icesheet was being formed, Professor E. W. Hilgard finds evidence that the interior of our continent northward, about the sources of the Mississippi, was then uplifted not less than 3,000 feet above its present height. Iikewise the fjords of Scotland and its adjacent island groups, and especially the much deeper fjords of Scandinavia, prove for that glaciated region an altitude thousands of feet higher than now, the maximum depth of the Sogne fjord, the longest in Norway, being stated by Jamieson as 4,080 feet. In the same way, New Zealand and Patagonia, formerly glaciated, are remarkable for their abundant, long and branching fjords. But the most surprising known submerged continuation of any river valley is that of the Congo, which, according to Mr. J. Y. Buchanan, is determined, by soundings for a cable to connect commercial stations on the west African coast, to be about eighty miles long, descending to the profound depth of 6,000 feet below the sea level.

The Congo valley, only about four hundred miles south of the equator, proves that the epeirogenic uplifts, causing glaciation, were not limited to drift-bearing regions. Where the uplifted areas were in so high latitudes, both north and south, that their precipitation of moisture gave snowfall during all, or nearly all, the year, they began to be covered by snow, which became consolidated below into ice and grew in depth to hundreds and thousands of feet.

Why the earth during the Glacial period was extraordinarily deformed for comparatively short periods by great epeirogenic movements of elevation and correlative depression of other tracts, is a more fundamental and not less difficult question, for which $I$ have attempted an answer in an appendix of Wright's "Ice Age in North America," ascribing these movements to stress stored up previous to its relief by the folding, overthrust and upheaval of mountain ranges. This explanation, although diverging widely from formerly assumed conditions of continental stability, seems yet well consistent with Dana's doctrine of the general permanence of the continents and oceanic basins.

\section{NOTES ON THE DISTRIBUTION OF SOME OF THE CONIFERS OF NORTH-WESTERN CANADA.}

BY J. B. TYRRELI, OF THE GEOLOGICAL SURVEY OF CANADA.

THe following observations on the limits of some forest trees were made while conducting geological surveys in the interior of northwestern Canada, in the country extending from Lake Winnipeg northwestward to the Athabasca River.

White Spruce (Picea alba) is the most important timber tree of this whole region. It occurs throughout the heavily wooded districts from Riding and Duck Mountains, in northern Manitoba, northwestward to the great forest region between the Saskatchewan and Churchill rivers, and thence westward beyond the Athabasca. North of the upper part of Churchill River it extends into the rocky granite country for a short distance and then disappears, so that its general northern limit is here reached at, or south of, the height of land; but while the writer was travelling across Little Hatchet Lake, in north latitude $58^{\circ} 40$ and west longitude $103^{\circ} 45$, a high sandy island was found on which was a small grove of tall white spruce, some trees with a diameter of fifteen inches. None others were seen anywhere in the vicinity. This grove, therefore, forms a little outlier in the surrounding scattered forest of small black spruce and Banksian pine, the hill of warm dry sand furnishing it with a sufficently congenial home. Extending in from the west the white spruce occurs on and around the shores of Lake Athabasca, but it does not appear to grow at any great distance back from the lake. Black Spruce (Picea nigra) is usually a smaller tree than the last, and is scattered on the low lands everywhere thoughout the forest regions of the Province of Manitoba, and the District of Saskatchewan, but north of the Churchill River, and southeast of Lake Athabasca it often ascends to the higher lands. Its northern limit for this region has not yet been traced. Balsam Fir (Abies balsamea) grows to a large size among the white spruce on the top and sides of the Duck Mountain in Manitoba, and between the Saskatchewan and Churchill rivers in the District of Saskatchewan. It 